\title{
Progettisti a fumetti: quando la nona arte parla di progetto
}

\author{
Sara Conte \\ Valentina Marchetti
}

Abstract

Nonostante il fumetto rappresenti ancora un genere per alcuni aspetti di nicchia, negli ultimi anni si assiste a un momento di estrema vivacità editoriale che sottolinea le connessioni tra questi linguaggi narrativi e il mondo del design e dell'architettura. Quest'influenza, mai a senso unico, affonda le sue radici nella storia dell'architettura stessa, che a partire dagli anni '60 con gli Archigram e prima con Le Corbusier, si confronta con il tema dell'ibridazione linguistica dando vita ad archi-fumetti e fumetti infografici. Nell'eterogenea produzione editoriale attuale risultano di particolare interesse dal punto di vista della rappresentazione le 'biografie a fumetti'; un sottogenere in forte espansione che coinvolge principalmente il mondo della musica e dell'arte, ma che grazie alla recente collana proposta dalla casa editrice Centauria mostra negli ultimi dieci anni interesse anche verso l'area del progetto. Opere dedicate al lavoro e alla vita di progettisti come Le Corbusier, Sottsass, van der Rohe consentono interessanti riflessioni sulla modalità di comunicazione del processo progettuale e di rappresentazione delle opere. Tra queste, la presente ricerca si concentra su tre biografie edite nel 2019, dedicate ad altrettante progettiste: Eileen Gray, Lina Bo Bardi e Charlotte Perriand. Questi volumi indagano vita e lavoro di queste donne, dando il giusto spazio al loro ruolo nella storia e interpretando, in modi differenti, il loro apporto attraverso il disegno e il colore.

Parole chiave

illustrazione, fumetti, design, architetti, biografie.

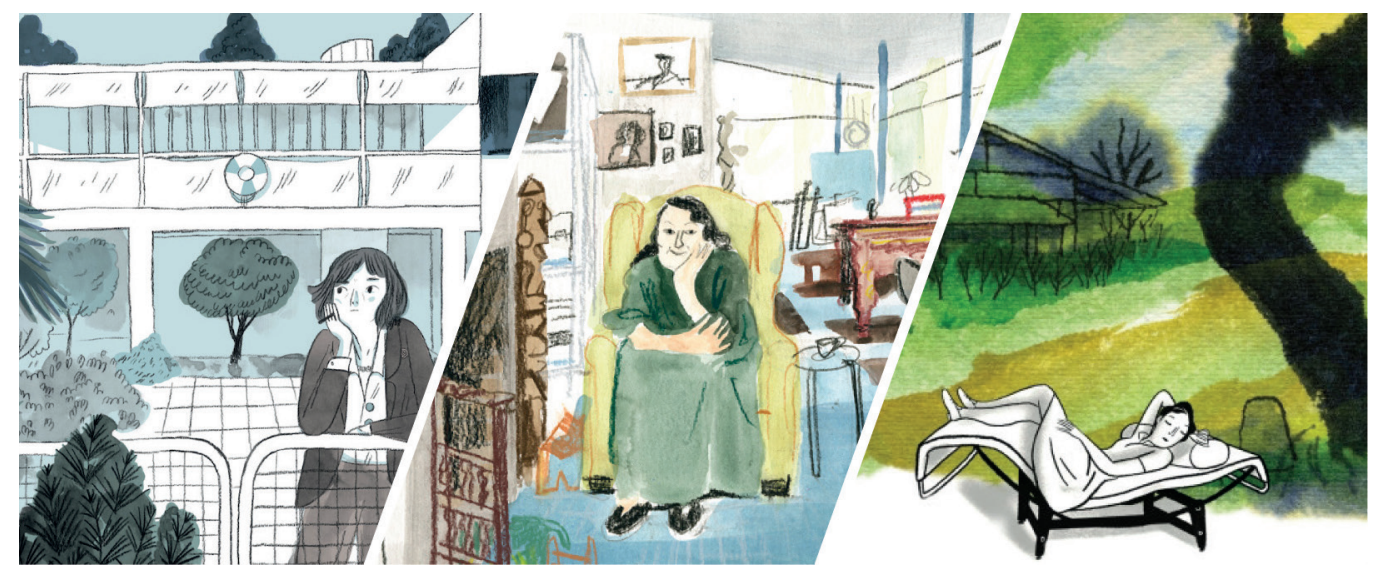




\section{Introduzione}

L'odierna definizione di fumetto ha radici antiche ed è il risultato dei mutamenti della società che viene in esso rappresentata [I]. La narrazione per immagini nasce infatti con la necessità dell'uomo di comunicare; graffiti e pitture rupestri dal carattere propiziatorio, geroglifici che nella sintesi dei segni narrano eventi di ogni genere, fregi che celebrano gesta di condottieri sono solo alcuni degli esempi dell'utilizzo dell'immagine per comunicare un messaggio a un vasto pubblico in modo semplice, immediato e universale. Tuttavia, è solo con la fine del XVIII secolo che nella cultura occidentale si può stimare l'inizio di una visione consapevole della tecnica. La nascita del genere fumetto, considerato come una narrazione composta da elementi esclusivamente grafici, si fa coincidere con il 5 maggio I895, quando l'artista americano Richard Felton Outcalt iniziò a disegnare sul supplemento domenicale del New York World una strip dal titolo Hogan's Alley, successivamente rinominata The Yellow Kid in onore del protagonista: un bambino irlandese vestito di giallo partecipante attivo degli avvenimenti del quartiere. In Europa però, pochi anni prima dell'uscita della striscia americana, l'illustratore ginevrino Rodolphe Töpffer, montando in sequenza immagini e testo separati da una riga orizzontale, realizzava per i suoi allievi delle brevi storie illustrate. Queste, apparse separatamente a partire dal 1833, vennero raccolte nel 1846 sotto il nome di Histoires en estampes dando vita ad un nuovo linguaggio: il fumetto.

Anche nella cultura orientale la narrazione per immagini ha radici antiche; in Giappone i primi esempi di testi illustrati sono gli emakimono del periodo Heian (740- I | 85), rotoli che associano immagini a brevi testi calligrafati, ma anche in questo caso la nascita del manga è difficilmente databile [Berndt 2009]. Per molti esperti [Kinko 2008] coincide con l'introduzione nel 1862 delle strisce comiche satiriche con balloon di stampo americano che danno vita alla rivista The Japan Punch. Tuttavia, la parola manga era già stata utilizzata nel I 8 I 5 dal pittore Hokusai Katsushika come titolo per una raccolta di disegni umoristici, Hokusai Manga, il cui significato letterale è 'immagini divertenti' o 'immagini in movimento'. Nel corso dei secoli grazie alla diffusione della stampa e all'assunzione di un proprio linguaggio, il fumetto, nato come fenomeno culturale marginale, si è ritagliato un importante spazio all'interno della società, entrando a far parte a partire dagli anni '60 dei media più diffusi [Eco 20 I0] e conseguendo successivamente lo status di arte. Nel saggio Comics and sequential art, pub-

Fig. I.A sinistra le strisce di Histoire de monsieur jabot di RodolpheTöpffer del 1833; a destra immagine estratta da Manga vol. 8 della metà del 1800.
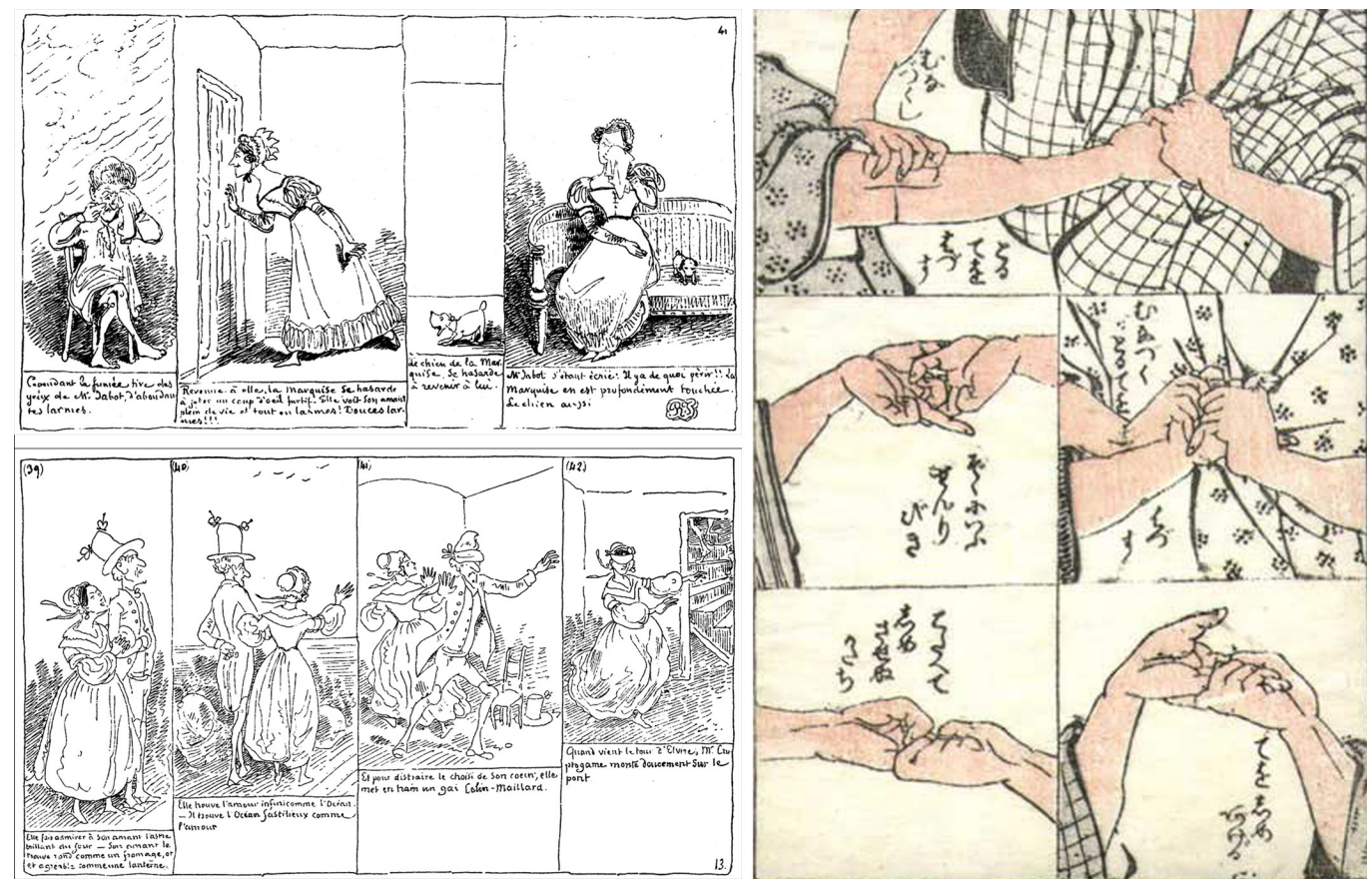
blicato per la prima volta nel 1985, Will Eisner, padre della odierna graphic novel, definisce il fumetto come arte sequenziale: ovvero un medium che si avvale della giustapposizione tra immagine e testo in una sequenza ordinata [Eisner 20 I0].

Questa definizione, estendibile a molte forme di rappresentazione, pone l'accento sulla dimensione fondamentale e costitutiva del fumetto: il tempo. Indipendentemente da tecnica grafica, struttura e temi trattati è la dimensione narrativa, costruita attraverso la sequenza di illustrazioni, la radice che accomuna tutte le variazioni di quest'arte. Sono proprio i temi di spazio e tempo che permettono ad architettura e fumetto di intrecciarsi e contaminarsi attraverso il disegno, in quanto una è l'arte della costruzione dello spazio e l'altra della rappresentazione del tempo (fig. I).

\section{Intrecci tra architettura e fumetto}

Il disegno d'architettura non si limita alla rappresentazione di elementi che verranno poi costruiti, ma è innanzitutto la concretizzazione di una visione, la prefigurazione della trasformazione di uno spazio, la proiezione di un'idea nella mente del progettista. Un'idea che ha la necessità di essere comunicata oltre la sua dimensione estetica attraverso il racconto di ciò che sarà. Allo stesso tempo, il disegno è un potente strumento di critica in grado di supportare una riflessione pratica e teorica sul mondo, costruito o immaginato. II medium del fumetto, per la capacità unica di riunire con una comunicazione efficace e immediata il concetto di tempo, spazio e movimento, superando la rigidità dei disegni tecnici codificati ha sempre affascinato gli architetti, al punto che già Le Corbusier negli anni Venti ha sperimentato un proto-fumetto per comunicare con i propri clienti. Nella lettera del 1925 a madame Meyer, l'architetto, inspirato dal lavoro di Töpffer, attua una scelta consapevole nell'uso di un mezzo nuovo, spiegando l'idea di progetto con una narrazione sequenziale e graficamente sintetica attraverso l'esperienza temporale dell'architettura.

Tuttavia, si dovrà attendere il 196I per vedere Peter Cook e Archigram realizzare il primo archifumetto: Amazing Archigram 4. Analizzando le pubblicazioni e i progetti degli ultimi 30 anni è evidente il crescente interesse nella sovrapposizione tra architettura e narrativa grafica. La necessità di rappresentare la complessità del pensiero architettonico e di riavvicinare il mondo dell'architettura al mondo del fruitore dell'opera stessa sono solo alcune delle ragioni che spingono gli architetti a indagare nuove possibilità di esplorare lo spazio [Conte, Marchetti 2020]. La contaminazione, tuttavia, non è a senso unico; infatti, la particolare propensione del fumetto nell'esplorazione dello spazio architettonico nasce con il mezzo stesso. L'architettura viene usata dal fumetto come medium per sperimentare nuovi metodi di costruzione del tempo narrativo, per muovere critiche alla società o all'architettura stessa; sfrutta la sua potenza simbolica per consentire ai lettori d'identificare gli scenari urbani di sfondo o per immergerli in mondi fantastici e suscitare meraviglia [Cassarà, D'Urso 20 I3]. Gli ultimi anni hanno inoltre visto la diffusione di un nuovo sottogenere, che vede nella storia reale, personale e autobiografica un terreno fertile per la narrativa a fumetti. Sono proliferate biografie di personaggi storici, musicisti, scienziati, sportivi, artisti e naturalmente anche progettisti. Celebri sono lavori come Kurt Cobain, quando ero un alieno di Deninotti e Bruno o Nevermind, We are the champions ed Enigma. La strana vita di Alan Turning di Tuono Pettinato. La casa editrice Centauria, a rimarcare il diffuso interesse al genere, ha dedicato agli artisti un'intera collana intitolata Graphic Biography, che annovera tra le pubblicazioni opere come Pollock confidential di Catacchio, Francis Bacon, La violenza di una rosa di Portolano, Edward Hopper. Pittore del Silenzio di Scarduelli e Rossi, Egon Schile. II corpo struggente di Gabos e molti altri (fig. 2). Nelle biografie di artisti, come in quelle di architetti o designer, è presente una ricerca stilistica nella rappresentazione che, pur non snaturando l'identità del fumettista, dialoga con lo stile del soggetto rappresentato, esaltandolo. In questo senso si aprono interessanti riflessioni sulla comunicazione delle scelte artistiche o progettuali sottese alle opere e di quelle estetiche o formali: in alcuni casi si notano disegni ricercati, dove lo stile di rappresentazione ricalca o enfatizza quello del soggetto rappresentato, mentre in altri si nota un approccio stilistico più neutro. 


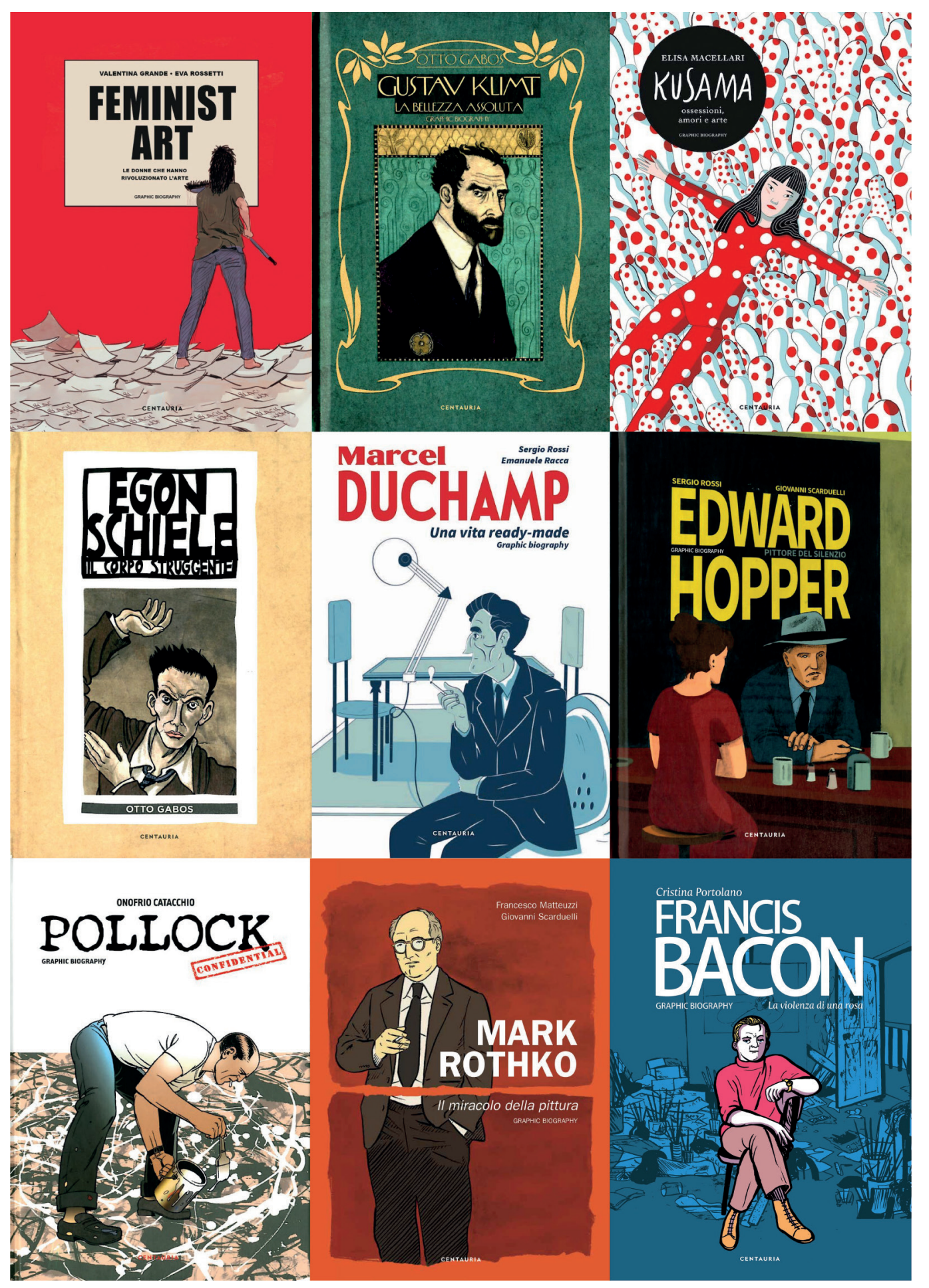


Biografie a fumetti al femminile

Raccontare storia, vita e lavoro di un "personaggio creativo", comporta una serie di riflessioni sulla modalità di rappresentazione del processo progettuale o artistico celato dietro le opere e che mediante l'uso di segni grafici e del colore si deve chiaramente ed emotivamente comunicare e trasporre. Negli ultimi anni si devono al fumetto interessanti lavori che vedono come soggetti, celebri o un po' dimenticati, designer e architetti (fig. 3). Tra queste si trovano opere volte a ritrarre le molteplici sfumature della vita di Le Corbusier, come i lavori Le Corbusier, architecte parmi les hommes, di Baudouï, Thévenet, Rebena e la serie di tavole Infographic: The Life of Le Corbusier di Mahé, autobiografie su Sottsass come Ettore. Mr Sottsass Jr e il mistero degli oggetti di Giacon, traposto in episodi animati per Kartell, oppure il recente Mies di Ferrer Casa. A questi si affiancano lavori che riscoprono figure femminili, talvolta messe in ombra ma che oggi sono interessante oggetto di indagine anche attraverso il fumetto.

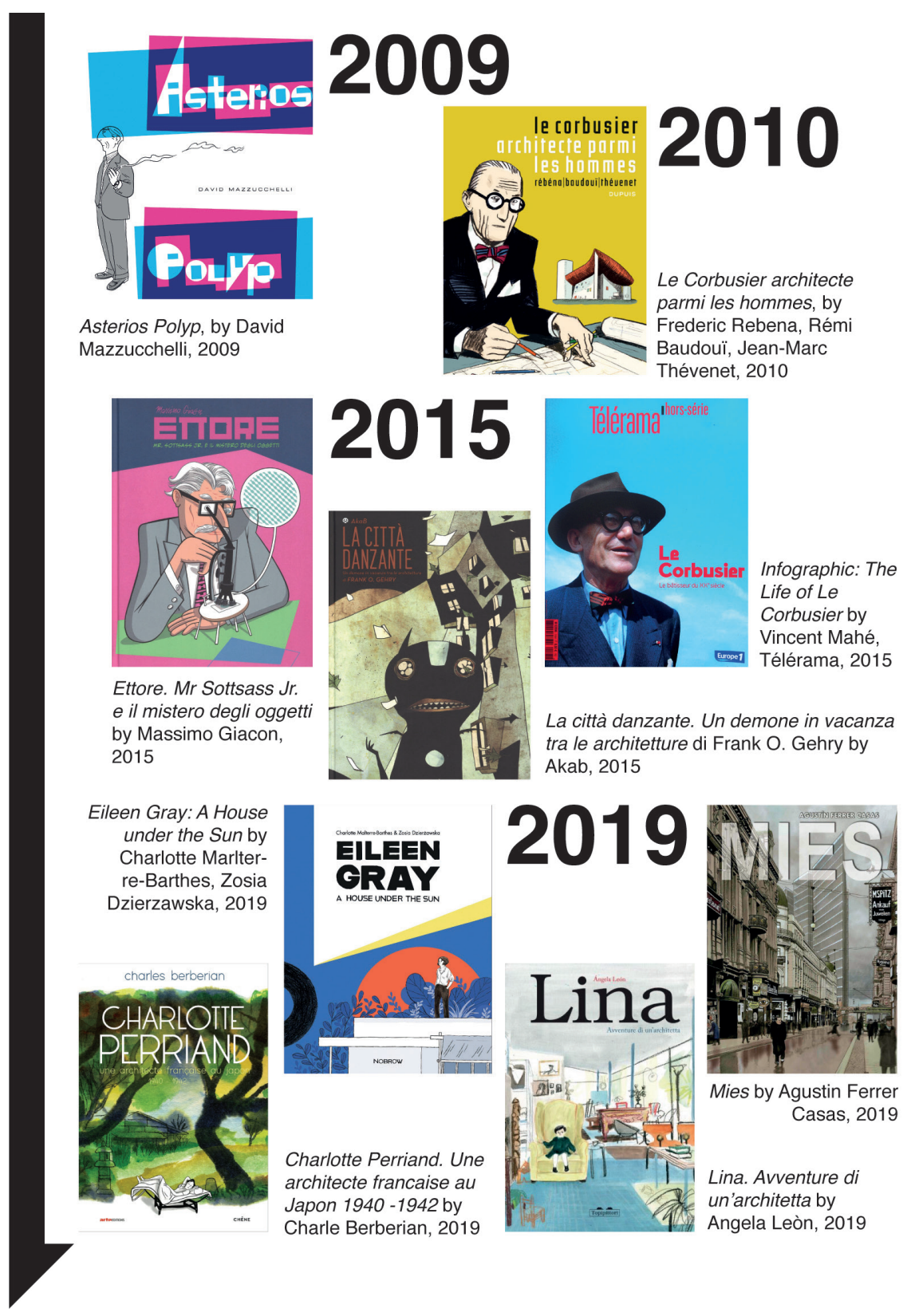


II primo caso in esame è Eileen Gray:A House Under the Sun di Charlotte Malterre-Barthes e Zosia Dzierzawska. L'opera, che indaga la protagonista dal punto di vista di progettista (designer, architetto e artista), femminista e non ultimo donna, concentra però l'attenzione del lettore sulla realizzazione della villa E. I 027 a Roquebrune-Cap-Martin; le tavole che raccontano la genesi del progetto sono tra le più interessanti dal punto di vista della rappresentazione. Le vignette si sgretolano nel flusso di pensieri della progettista e la rappresentazione tecnica bidimensionale irrompe in quella tridimensionale della storia narrata, supportando la fisicità dei personaggi (fig. 4). La scelta cromatica è raffinata e funzionale alla comunicazione: gli anni relativi alla E. I027 sono connotati dall'uso del bianco e dei toni del grigio-azzurro contrapponendosi alle tinte sgargianti utilizzate per rappresentare l'intervento artistico di Le Corbusier. Quest'ultimo infatti deturpa e distrugge l'armonia creata dalla Gray nella propria casa, sensazione accentuata dalla scelta cromatica e dalla contrapposizione di ordine e disordine delle vignette portata avanti dalle fumettiste. Simbolica all'interno della narrazione è anche la scelta di rottura grafica del layout rigido della pagina che permette alle autrici di rappresentare momenti chiave della vita della progettista: il flusso di coscienza, il processo progettuale, un'architettura, un luogo importante o particolari sequenze personali dove
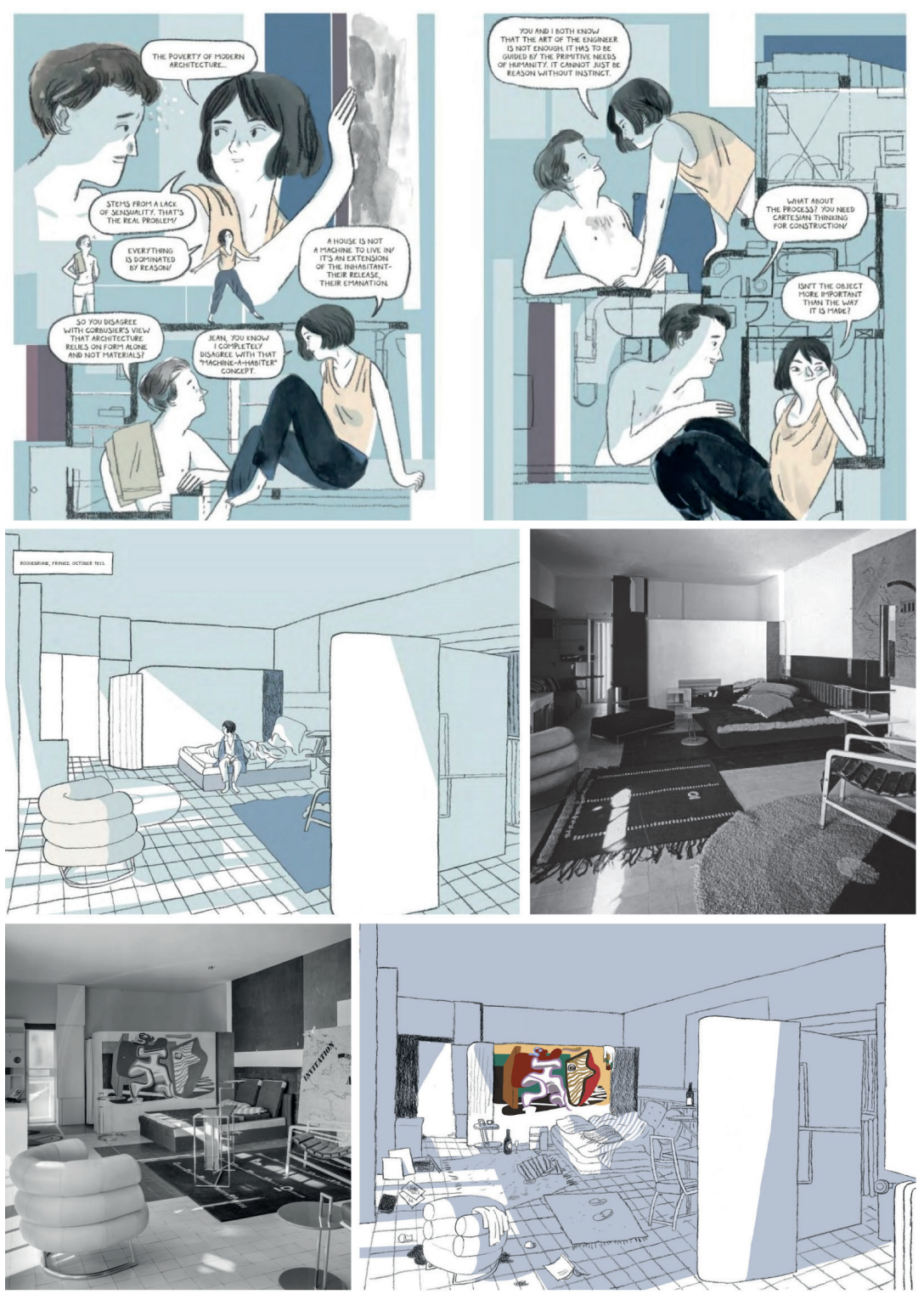
il ritmo degli eventi è concitato e non lineare. Differente è la sperimentazione portata avanti da Angela Leon nel fumetto, pensato prevalentemente per bambini, Lina. Avventure di un'architetta. II target impone alcune scelte di rappresentazione, soprattutto sulla parte del lettering, che viene sdoganato dai balloon diventando spesso voce narrante di avvenimenti e pensieri. Nonostante ciò, il lavoro della fumettista spagnola riesce, in alcuni passaggi, a indagare il lavoro dell'architetto e le sue influenze attraverso raffigurazioni iconografiche semplici ed efficaci. I tratti, che in parte rimandano al disegno per bambini, non sminuiscono la rappresentazione del soggetto grazie alla scelta delle inquadrature e al bilanciamento tra immagine e sfondo. Nella resa della Superleggera di Gio Ponti, ad esempio, si richiamano le fotografie di Casali utilizzate per le pubblicità, oltrepassando la mera raffigurazione dell'oggetto e indagando le modalità di comunicazione adottate storicamente (fig. 5).

Ultimo lavoro qui preso in esame è Charlotte Perriand. Une architecte française au Japan 1940-1942 di Charles Berberian, dove è evidente un'oculata scelta stilistica volta alla rappresentazione del contesto culturale nel quale la storia è ambientata. II volume si concentra su un preciso periodo della vita della Perriand, quello del suo viaggio in Giappone, ed è diviso in due parti: la prima racconta l'esperienza dell'architetto a partire dall'abbandono dello studio di Le Corbusier, la seconda invece raccoglie l'intervista alla figlia Permette, accompagnata da illustrazioni di mobili realizzati dalla madre e di personaggi del periodo trascorso in Giappone. II layout delle tavole è abbastanza tradizionale e segue una rigida
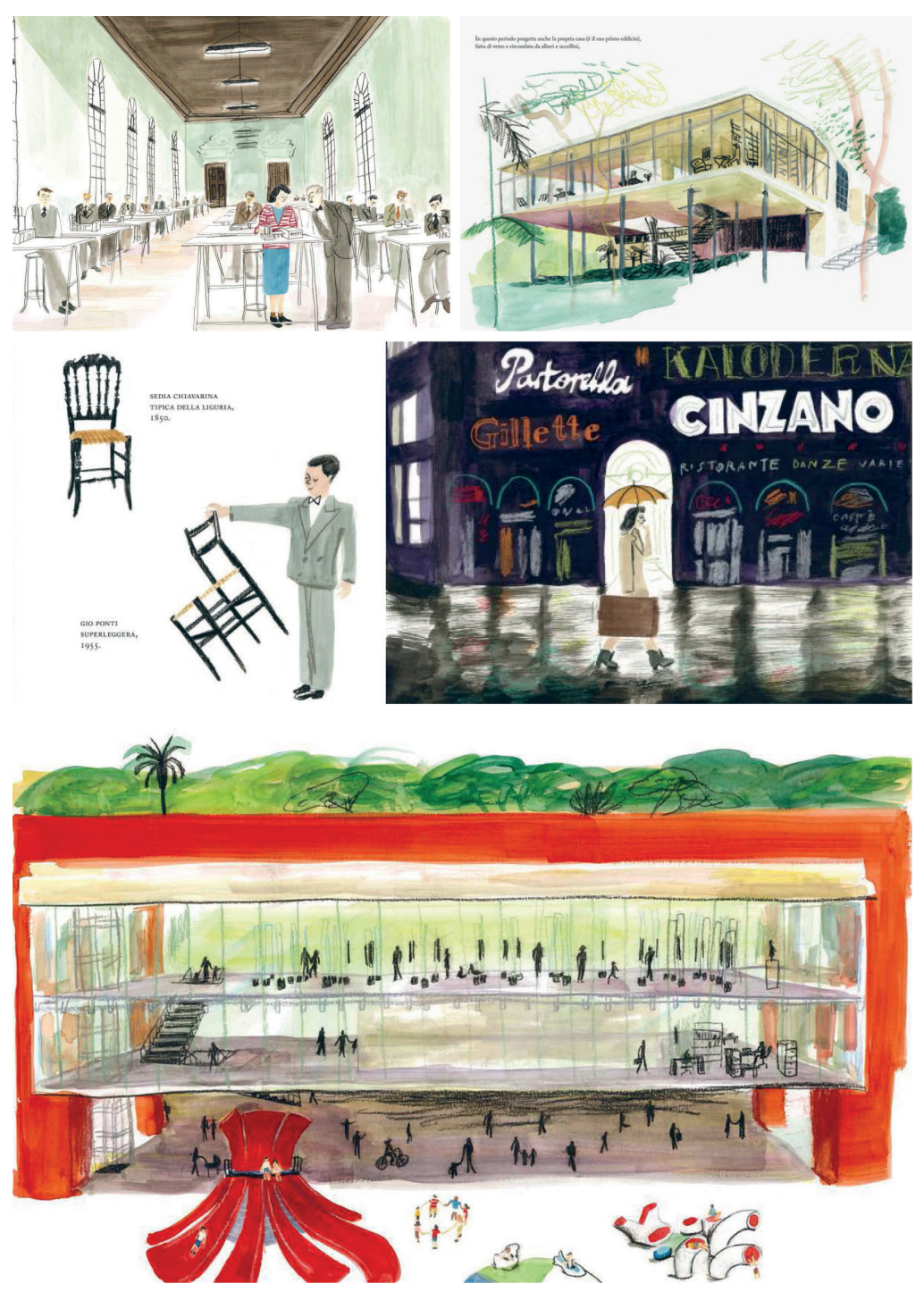
griglia compositiva. Peculiari sono invece le scelte cromatiche, l'uso del segno grafico e la commistione delle tecniche di rappresentazione. Gran parte del racconto è caratterizzato da vignette a fondo panna, dove il tratto nero rimanda allo shodō giapponese, arte della scrittura calligrafica tradizionale. Lo stile di tutta l'opera guarda esplicitamente alla cultura orientale divenendo così simbolo delle influenze e della ricerca stilistica della protagonista. Durante il viaggio la Perriad assimila vari aspetti della cultura tradizionale e artigianale del Sol Levante interiorizzandoli e traendone ispirazione per i propri progetti. Questa ricerca è sottolineata dall'autore inserendo delle pagine a quadretti, come pagine di un taccuino di viaggio, a volte in primo piano altre come sfondo dei discorsi tra Charlotte e un corvo con gli occhiali, onnipresente figura simbolica del maestro del movimento moderno. Dal punto di vista cromatico non vi è ricerca di realismo: il colore, influenzato dalla tecnica a inchiostro sumi-e giapponese, è emotivo e simbolico. Cromia dominante è l'azzurro-blu utilizzato in molti dei momenti riflessivi della protagonista, nelle scene notturne o come colore di accento per dettagli, ricordi o passaggi importanti, quali ad esempio l'abbandono dell'agenzia per poter firmare direttamente i propri lavori o lo studio delle tecniche costruttive tradizionali giapponesi. Giallo e ocra si aggiungono in alcuni scorci paesaggistici, mentre il rosso è introdotto in modo predominante solo a rappresentare l'attacco a Pearl Harbor e il cambiamento della situazione politica alla fine del 194I. La seconda parte del volume contiene schizzi di progetto riproposti, spesso mettendo in evidenza una quadrettatura
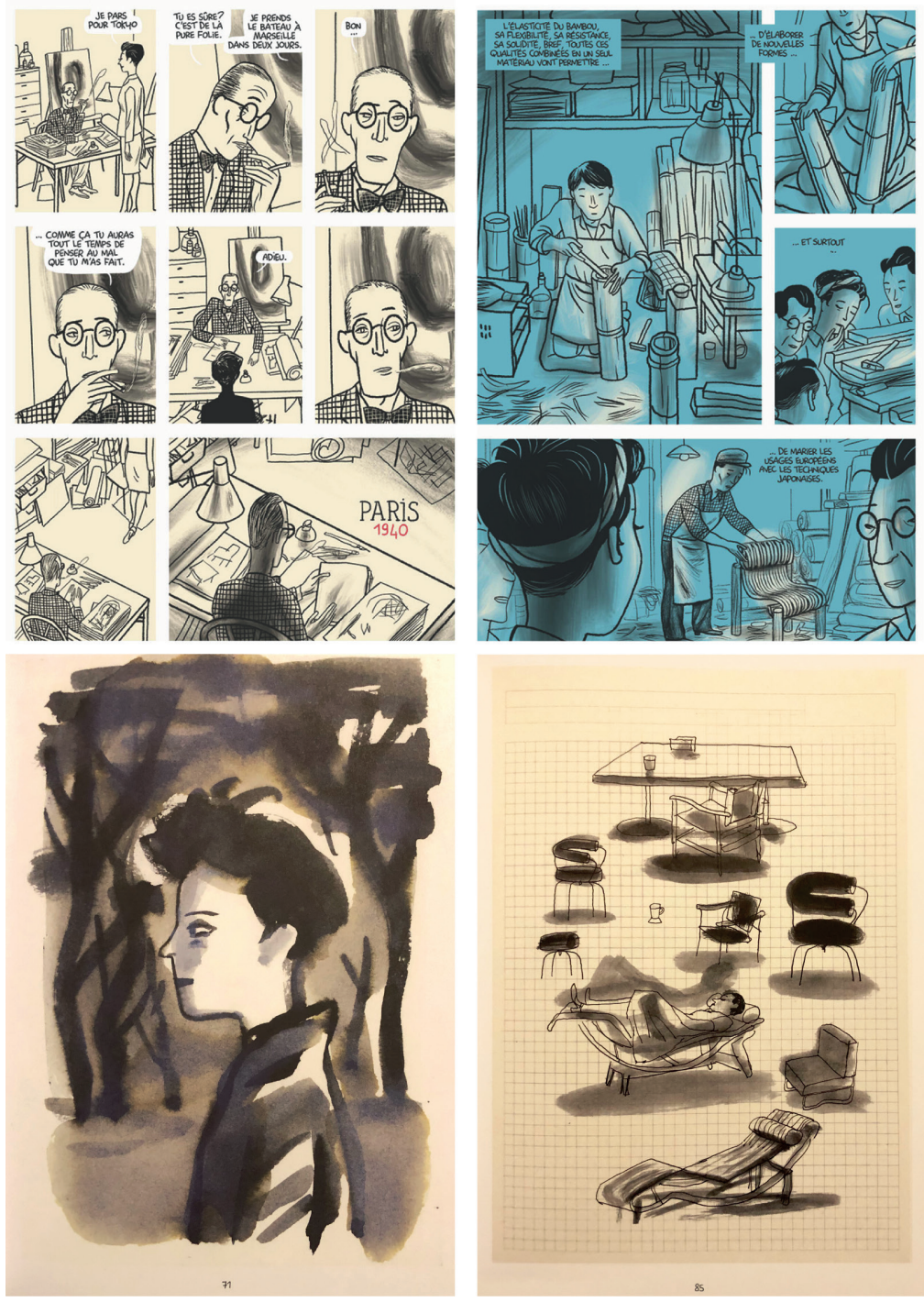
di fondo, seguendo lo stile proposto da Berberian nella prima parte del fumetto. Queste tavole si concentrano anche su dettagli del periodo giapponese, mostrando costumi tipici tradizionali, interni e persone con cui Charlotte Perriand si relaziona (fig. 6). Chiude l'opera una sintetica biografia dell'architetto.

\section{Conclusioni}

L'architettura non è la semplice costruzione di luoghi e spazi, ma è innanzitutto la proiezione materiale di un'idea nella mente del progettista, la concretizzazione di una visione e la creazione di un'atmosfera. La narrazione a fumetti, quando rende progettisti e architetture protagonisti delle sue storie, si concentra proprio su questa dimensione narrativa e lo fa attraverso la capacità unica di riunire, in modo efficace e immediato, i concetti di tempo, spazio e movimento propri del disegno.

Quest'ultimo è per il fumetto e l'architettura lo strumento della rappresentazione condiviso e come sottolinea Will Eisner, "bisogna tener presente che questo mezzo di comunicazione è visivo, e che il lettore assorbe il 'tono' della storia e altri concetti astratti attraverso i disegni”' [Eisner 2010, p. 33 I]. Le storie a fumetti diventano un modo di conoscere il mondo così come fa la pratica architettonica e permettono di cogliere aspetti che spesso passano inosservati. Per questo motivo le biografie di architetti e designer a fumetti, oltre a rimandare al legame indissolubile tra le due pratiche, rappresentano una scelta efficace e convincente per la comunicazione di contenuti immateriali che vanno oltre il progetto e oltre il progettista. Si prestano inoltre alla resa di scelte stilistiche, che vengono, attraverso il disegno, comunicate in modo semplice e intuitivo anche per i non addetti ai lavori.

\section{Note}

[I] Sebbene il paper sia stato concepito congiuntamente, Sara Conte è l'autrice dei paragrafi Introduzione e Intreccio tra architettura e fumetto e delle relative immagini, Valentina Marchetti è l'autrice dei paragrafi Biografie femminili a fumetti e Conclusioni e delle relative immagini.

\section{Riferimenti bibliografici}

Berberian C. (2019). Charlotte Perriand. Une architecte française au Japon (1940-1942). Paris: Editions du Chêne.

Berndt J. (1900). Manga and Manga: Contemporary Japanese Comics and their Dis/similarities with Hokusai Manga. In Civilisation of Evolution, Civilisation of Revolution, Metamorphoses in Japan 1900-2000, pp. 21 0-222.

Cassarà L., D'Urso S. (20। 3). Goodbye Topolinia.Catania: Malcor D'.

Eco U. (20।0). Apocalittici e integrati. Comunicazioni di massa e teorie della cultura di massa. Milano: Bompiani.

EisnerW. (20।0). Fumetto e arte sequenziale. In W. Eisner. L'arte del fumetto. Milano: Bur Rizzoli.

Kinko I. (2008). Manga in Japanese History. In M. MacWilliams (Ed.). Japanese Visual Culture: Explorations in the World of Manga and Anime. Armonk, N.Y.: Sharpe, pp. 26-48.

Leon A. (2019). Lina. Avventure di un'architetta. Milano:Topipittori.

Malterre Barthes C., Dzierzawska Z. (2019). Eileen Gray: A House Under the Sun. London: Nobrow Press.

McCloud S. (1999). Capire il fumetto. L'arte invisibile. Torino:Vittorio Pavesio Editore.

\section{Autori}

Sara Conte, Politecnico di Milano, sara.conte@polimi.it

Valentina Marchetti, Politecnico di Milano, valentina.marchetti@polimi.it

Per citare questo capitolo: Conte Sara, Marchetti Valentina (2021). Progettisti a fumetti: quando la nona arte parla di progetto/Designers in comics: when the ninth art talks about design. In Arena A., Arena M., Mediati D., Raffa P. (a cura di). Connettere. Un disegno per annodare e tessere. Linguagg Distanze Tecnologie. Atti del $42^{\circ}$ Convegno Internazionale dei Docenti delle Discipline della Rappresentazione/Connecting. Drawing for weaving relationship. Languages Distances Technologies. Proceedings of the $42^{\text {th }}$ International Conference of Representation Disciplines Teachers. Milano: Franco Angeli, pp. 548-565. 


\title{
Designers in Comics: When the Ninth Art Talks about Design
}

\author{
Sara Conte \\ Valentina Marchetti
}

Abstract

In these years the comics are living, despite the fact that they are still a niche genre in some aspects, a moment of extreme editorial vivacity that underlines the connections between these narrative languages and the world of design and architecture.

This never one-way influence has its roots in the history of architecture itself, which, starting in the 60 s with Archigram and before that with Le Corbusier, faces the theme of linguistic hybridization and gives life to archi-comics and infographic comics. 'Comics biographies' are, in the heterogeneous current editorial production, of particular interest from the representational point of view. This is a sub-genre in strong expansion, which mainly involves the world of music and art, the latter thanks to the recent series proposed by the publishing house Centauria, and which in the last ten years has also shown interest in the project sector. Graphic novels dedicated to the work and life of designers such as Le Corbusier, Sottsass, Mies allow interesting reflections on the way of communication and representation of the design process and of their works. Among them, the present research focuses on three biographies published in 2019 and dedicated to three female designers: Eileen Gray, Lina Bo Bardi and Charlotte Perriand. These volumes investigate the lives and work of these women, giving due space to their role in history and interpreting, in different ways, their contribution through drawing and color.

Keywords

illustration, comics, design, architect, biografy.

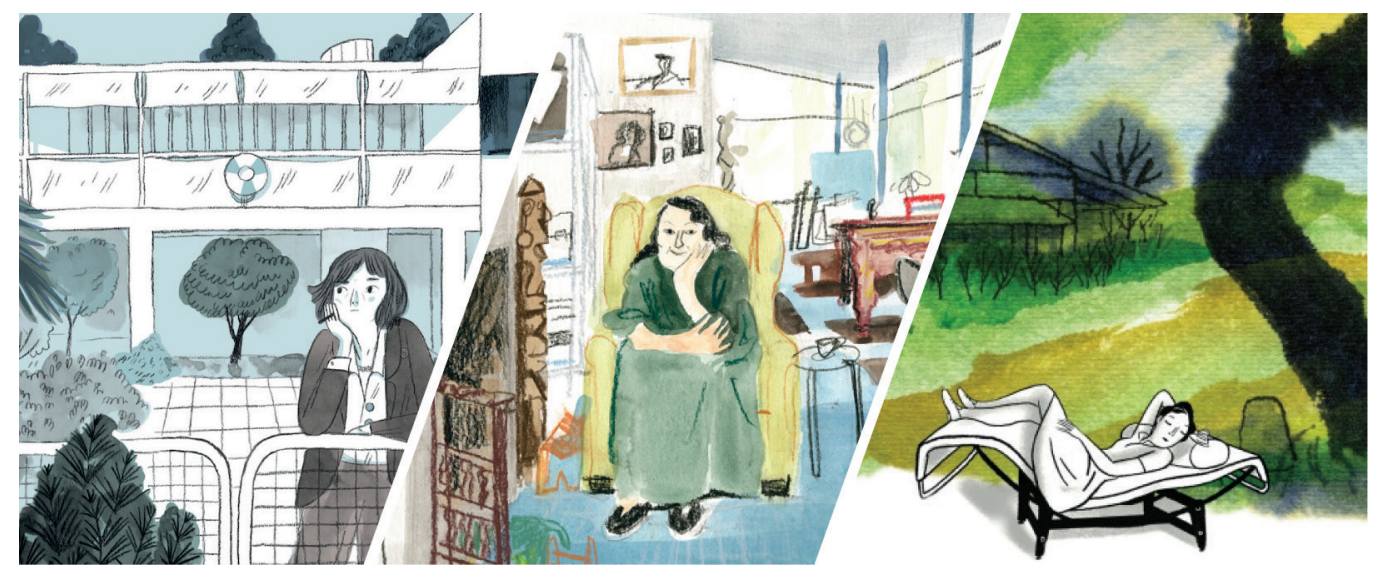




\section{Introduction}

The art of comics contemporary definition has ancient roots and is the result of changes in the society it represents [I]. The narration through images was born with the need of man to communicate: graffiti and cave paintings of propitiatory character, hieroglyphics that in the synthesis of signs narrate events of all kinds, friezes that celebrate the deeds of leaders are just some examples of the use of images to communicate a message to a wide audience in a simple, immediate and universal way. However, the beginning of a conscious vision of technique can be estimated, in Western culture, only in the end of the 18th century. The birth of the comic strip genre, considered as a narrative made up exclusively of graphic elements, coincides with May 5, I 895 when the American artist Richard Felton Outcalt began to draw, in the Sunday supplement of the New York World, the strip entitled Hogan's Alley. This was later renamed The Yellow Kid in honor of the protagonist: an Irish boy dressed in yellow who actively participated in the events of the neighborhood. However in Europe, the Genevan illustrator Rodolphe Töpffer, a few years before the release of the American strip, created short illustrated stories for his students by assembling images and text separated by a horizontal line. These, which had appeared separately since 1833, were collected in 1846 under the name of Histoires en estampes, giving rise to a new language: the comic.

The narration through images has ancient roots even in Eastern culture. In Japan the emakimono of the Heian period (740- I I 85), scrolls that associate images with short calligraphic texts, are the first examples of illustrated texts, but even in this case the birth of manga is difficult to date [Berndt 2009]. It coincides, for many experts [Kinko 2008] with the introduction in 1862 of American-style satirical comic strips with balloons that gave rise to The Japan Punch magazine. However, the word manga had already been used in 1815 by the painter Hokusai Katsushika as a title for a collection of humorous drawings, Hokusai Manga, whose literal meaning is 'funny pictures' or 'moving pictures'. Over the centuries, the comics, born as a marginal cultural phenomenon, have carved out, thanks to the spread of printing and the assumption of their own language, an important space in society, becoming part of the most popular media since the "60s [Eco 20l0] and then achieving the status of art. The father of today's graphic novel Will Eisner, in his essay Co-
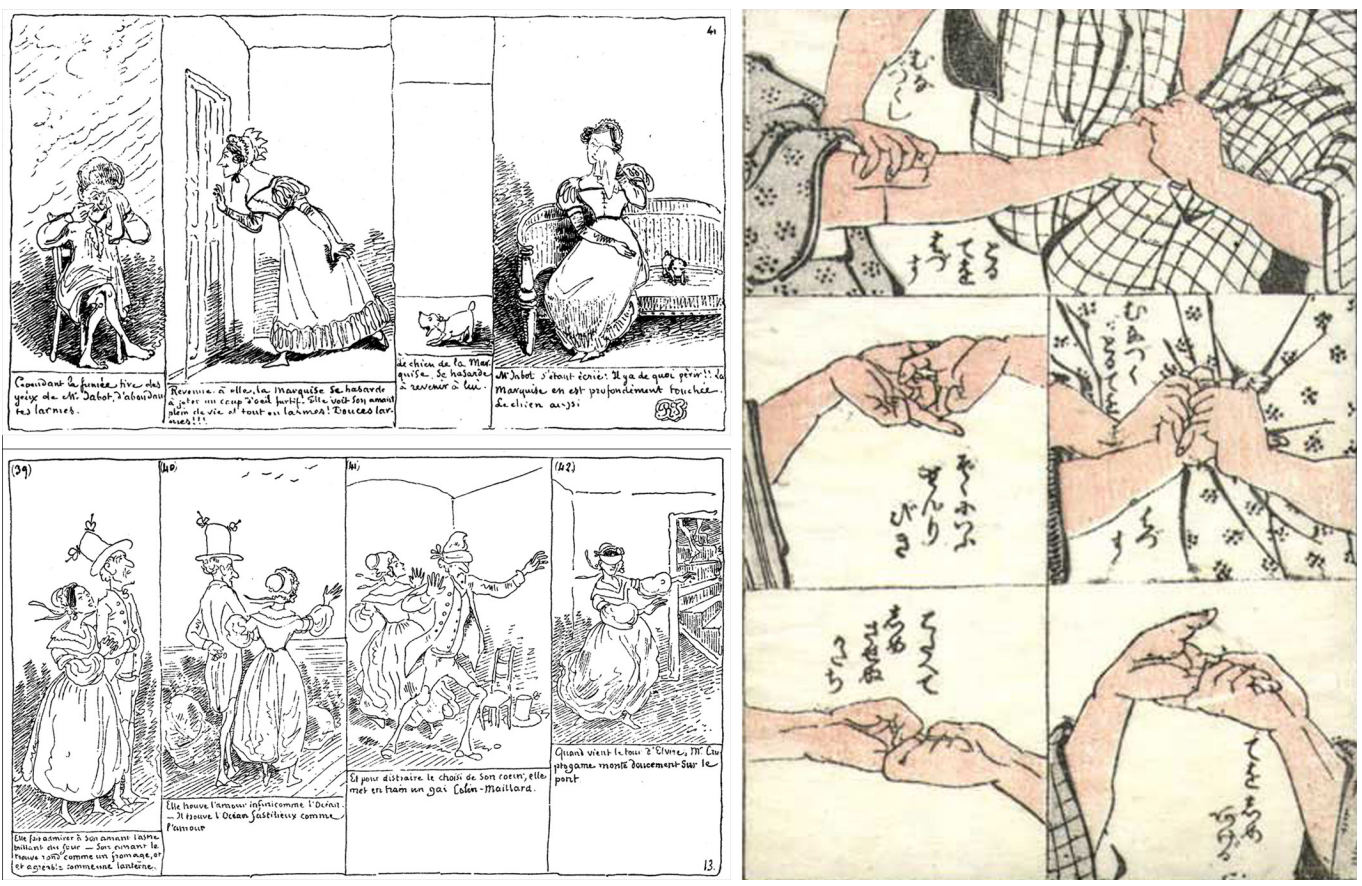
mics and sequential art, first published in 1985, defines comics as sequential art: a medium that makes use of the juxtaposition of image and text in an ordered sequence [Eisner 2010].

This definition, which can be extended to many forms of representation, emphasizes the fundamental and constitutive dimension of comics: time. The narrative dimension, built through the sequence of illustrations, is the root that unites all variations of this art, regardless of graphic technique, structure and themes. It is precisely the themes of space and time that allow architecture and comics to intertwine and contaminate each other through drawing, since one is the art of constructing space and the other of representing time (fig. I).

\section{Interweaving between architecture and comics}

Architectural drawing is not limited to the representation of elements that will later be built. It is mainly the concretization of a vision, the prefiguration of the transformation of a space, the projection of an idea in the designer's mind, that needs to be communicated beyond its aesthetic dimension through the future and possible story. At the same time, drawing is a powerful critical tool that can support a practical and theoretical reflection on the real or imagined world. The comics medium has the unique ability to bring together with an effective and immediate communication time, space and movement, overcoming the rigidity of codified technical drawings. It has always fascinated architects, indeed already Le Corbusier, during the twenties, designed a proto-comic book to communicate with his clients. The architect, inspired by the Töpffer's work, uses, in his letter (1925) to Madame Meyer, a new medium in a conscious way and it explains the project's idea choosing a sequential and graphically synthetic narration through the temporal experience of architecture. However, Peter Cook and Archigram realize the first archicomic, Amazing Archigram 4, only in the 1961. The growing interest in the overlap between architecture and graphic narrative is evident considering the analyzes of the publications and projects of the last 30 years. The need to represent the complexity of architectural thought and to bring the world of architecture closer to the users' ones are just some of the reasons that lead architects to investigate new possibilities to explore space [Conte, Marchetti 2020]. The contamination, however, is not a one-way process; in fact, the particular inclination of comics to explore architectural space originates with the medium itself. The comics use architecture as a medium to experiment with new methods of narrative time construction and to criticize the society or the architecture itself. This genre exploit its symbolic power to allow readers to identify urban background scenarios or to immerse them in fantastic worlds and arouse wonder [Cassarà, D'Urso 2013]. Recent years have also seen the spread of a new 'subgenre', which considers real, personal, and autobiographical history a fertile ground for comic book fiction. Biographies of historical figures, musicians, scientists, sportsmen, artists and of course designers have proliferated. Some famous works are Kurt Cobain, quando ero un alieno by Deninotti and Bruno or Nevermind, We are the champions and Enigma. La strana vita di Alan Turning by Tuono Pettinato. The publishing house Centauria, to emphasize the widespread interest in the genre, has dedicated to artists a series entitled Graphic Biography, which includes among its publications works such as Pollock confidential by Catacchio, Francis Bacon, La violenza di una rosa by Portolano, Edward Hopper. Pittore del Silenzio by Scarduelli and Rossi, Egon Schile, il corpo struggente by Gabos and many others (fig. 2). In the biographies of artists, as in those of architects or designers, there is a stylistic research of representation that, while not distorting the identity of the author, dialogues with the style of the represented subject, exalting it. Considering that, interesting reflections could be done regarding the communication of the artistic or design choices underlying the works, as well as the aesthetic or formal ones. In some examples, we can find refined drawings, where the style of representation follows or emphasizes the one of the represented subject, while in others we can notice a more neutral approach from a stylistic point of view. 


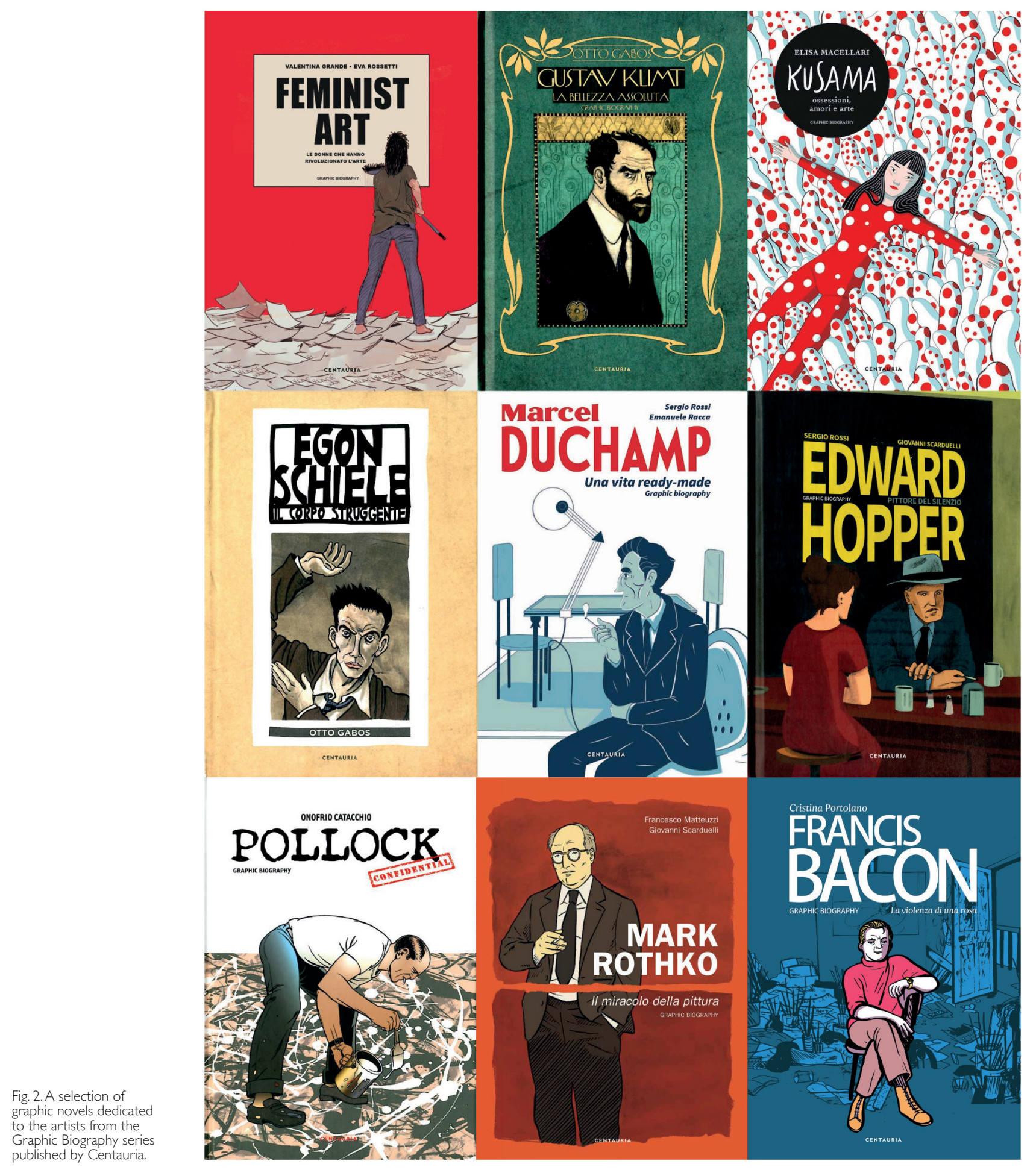




\section{Women's comics biographies}

Telling the story, life and work of a 'creative character' involves a series of reflections on the process to represent, through the use of graphic signs and color, the design or artistic process hidden behind the works, that should be communicated and transposed in a clear and emotional way. In recent years, celebrated or somewhat forgotten designers and architects have become the subjects of interesting comics (fig. 3). Among these, we find works aimed at portraying the many nuances of Le Corbusier's life, such as the works Le Corbusier, architecte parmi les hommes, by Baudouï, Thévenet, Rebena and the series of plates Infographic: The Life of Le Corbusier by Mahé, autobiographies on Sottsass as Ettore. Mr Sottsass Jr e il mistero degli oggetti by Giacon, translated into animated episodes for Kartell, or the recent Mies by Ferrer Casa. These are flanked by works that rediscover female figures, sometimes overshadowed and now becoming an interesting object of investigation also through comics.

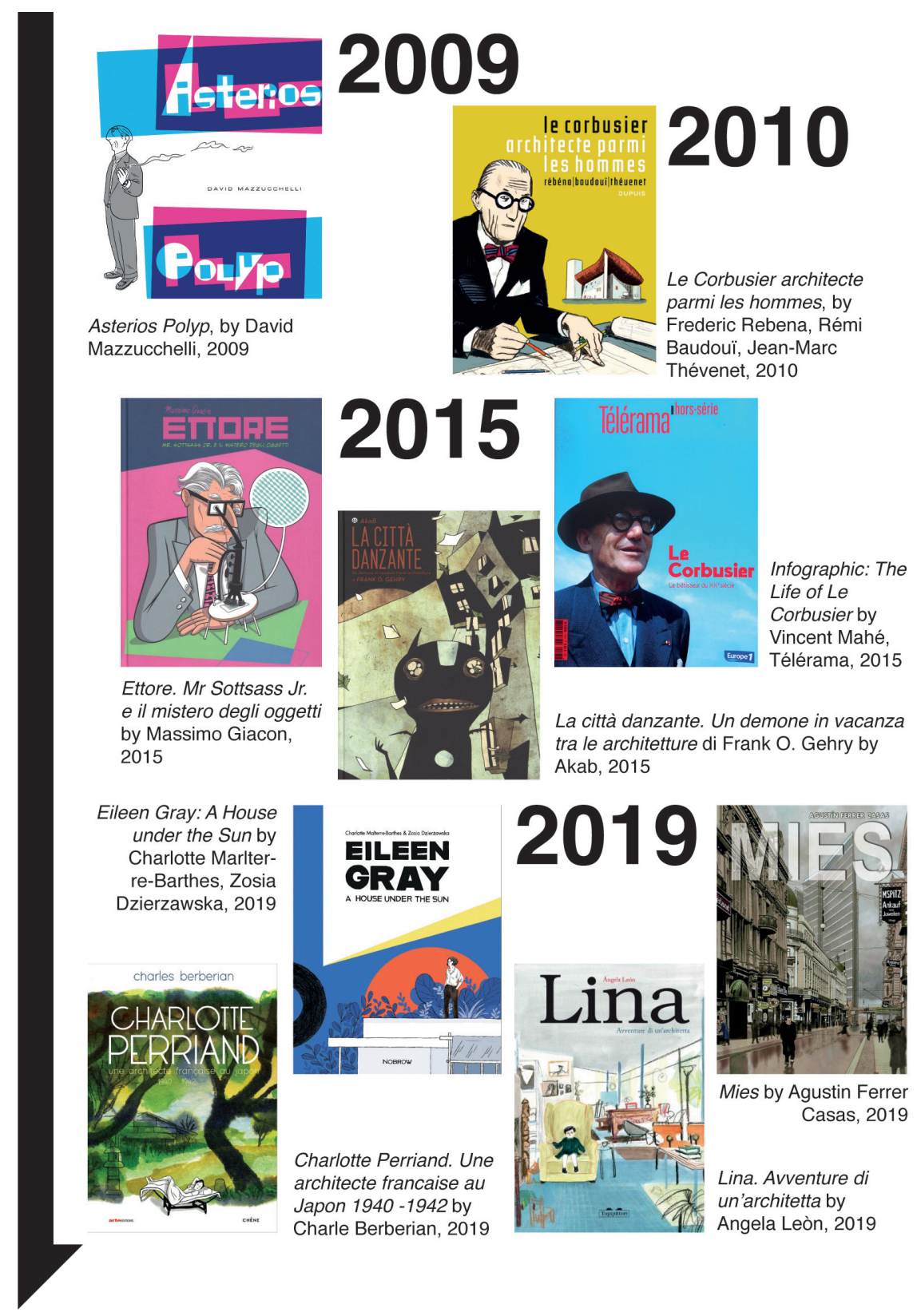


Eileen Gray:A House Under the Sun by Charlotte Malterre-Barthes and Zosia Dzierzawska is the first case under examination. The volume, which investigates Gray's character from the point of view of a designer, architect and artist, a feminist and, last but not least, a woman, focuses the reader's attention on the realization of villa E.I027 in Roquebrune-Cap-Martin. The illustrations that describe the genesis of the project are, in fact, among the most interesting from the representation point of view. The vignettes crumble in the designer's flow of thoughts and the two-dimensional technical representation breaks into the three-dimensional one of the narrated story, supporting the physicality of the characters (fig. 4). The chromatic choice is sophisticated and functional to the communication. The years relating to E. 1027 are characterized by the use of white and shades of gray-blue contrasting with the garish colors used to represent the artistic intervention of Le Corbusier. In fact, Le Corbusier disfigures and destroys the harmony created by Gray in her own house and this sensation is emphasized in the graphic novel by the chromatic choice and by the contrast of order and disorder of the vignettes. Also the choice of graphically breaking the rigid layout of the page is symbolic and it allows the authors to represent key moments of the designer's life like the stream of consciousness, the design process, an architecture, an important
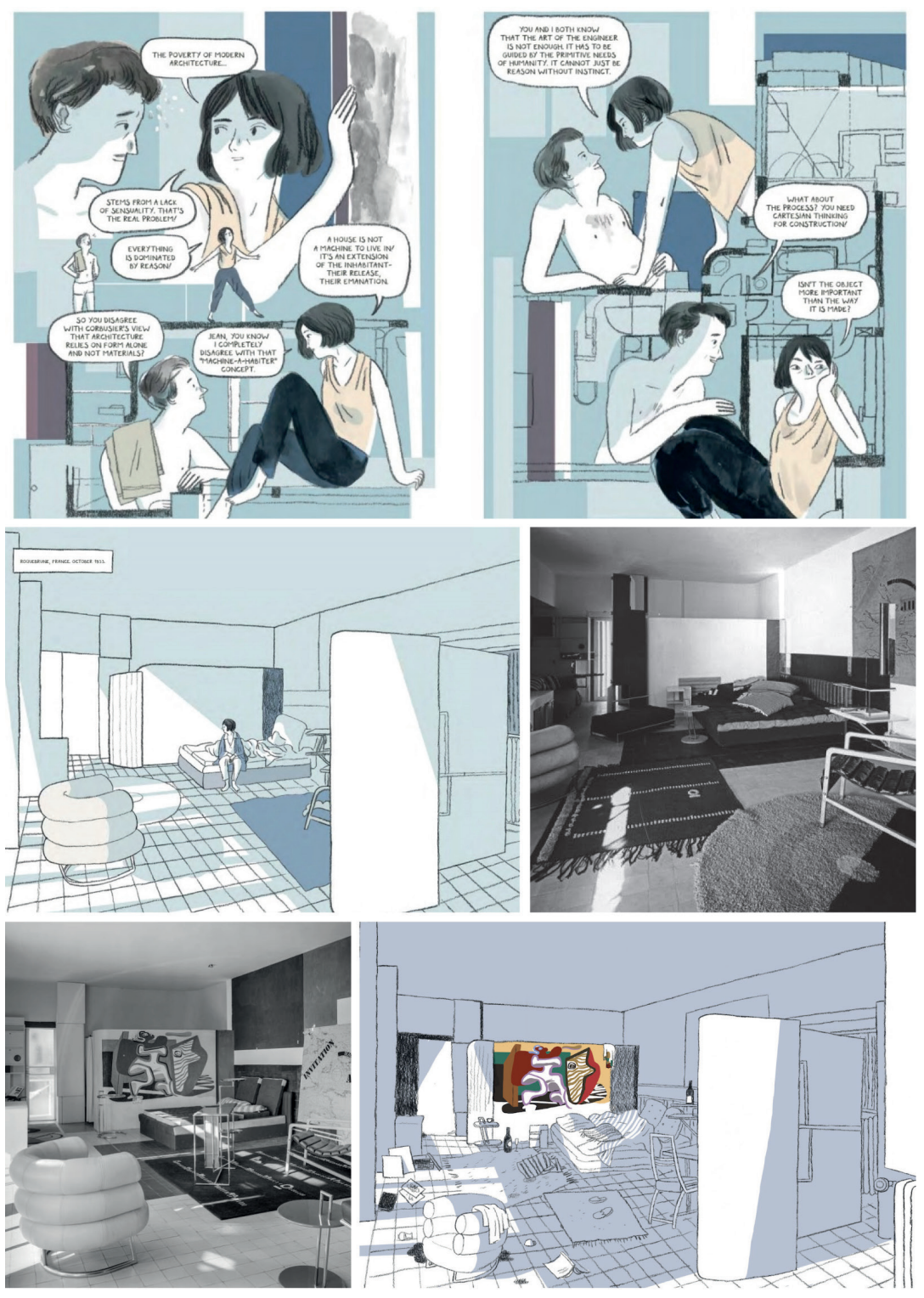
place or particular sequences, where the rhythm of events is concise and non-linear. The experimentation carried out by Angela Leon is different in the comic strip Lina. Avventure di un'architetta. Some representation choices are imposed by the addressed target, especially regarding the lettering, which is cleared by the balloons, often becoming the narrating voice of events and thoughts. Despite this, the work of the Spanish author manages, in some passages, to investigate the architect's work and his influences through simple and effective iconographic representations. The strokes, which in part evoke children's drawings, do not detract from the representation of the subject because of the choice of framing and the balance between image and background. The presentation of Gio Ponti's Superleggera, for example, recalls Casali's photographs used for advertising, going beyond the mere representation of the object and investigating the modes of communication historically adopted (fig. 5).

The last work examined here is Charlotte Perriand. une architecte française au Japan 19401942 by Charles Berberian, in which a careful stylistic choice is evident and is oriented towards the representation of the cultural context in which the story is set. The book concentrates on a precise period of Perriand's life, her journey to Japan, and is divided into two parts: the first relates the architect's experience starting from her abandonment of Le Corbusier's studio, while the second contains an interview with her daughter Permette. The latter is accompanied by illustrations of furniture made by Charlotte Perrinad and characters
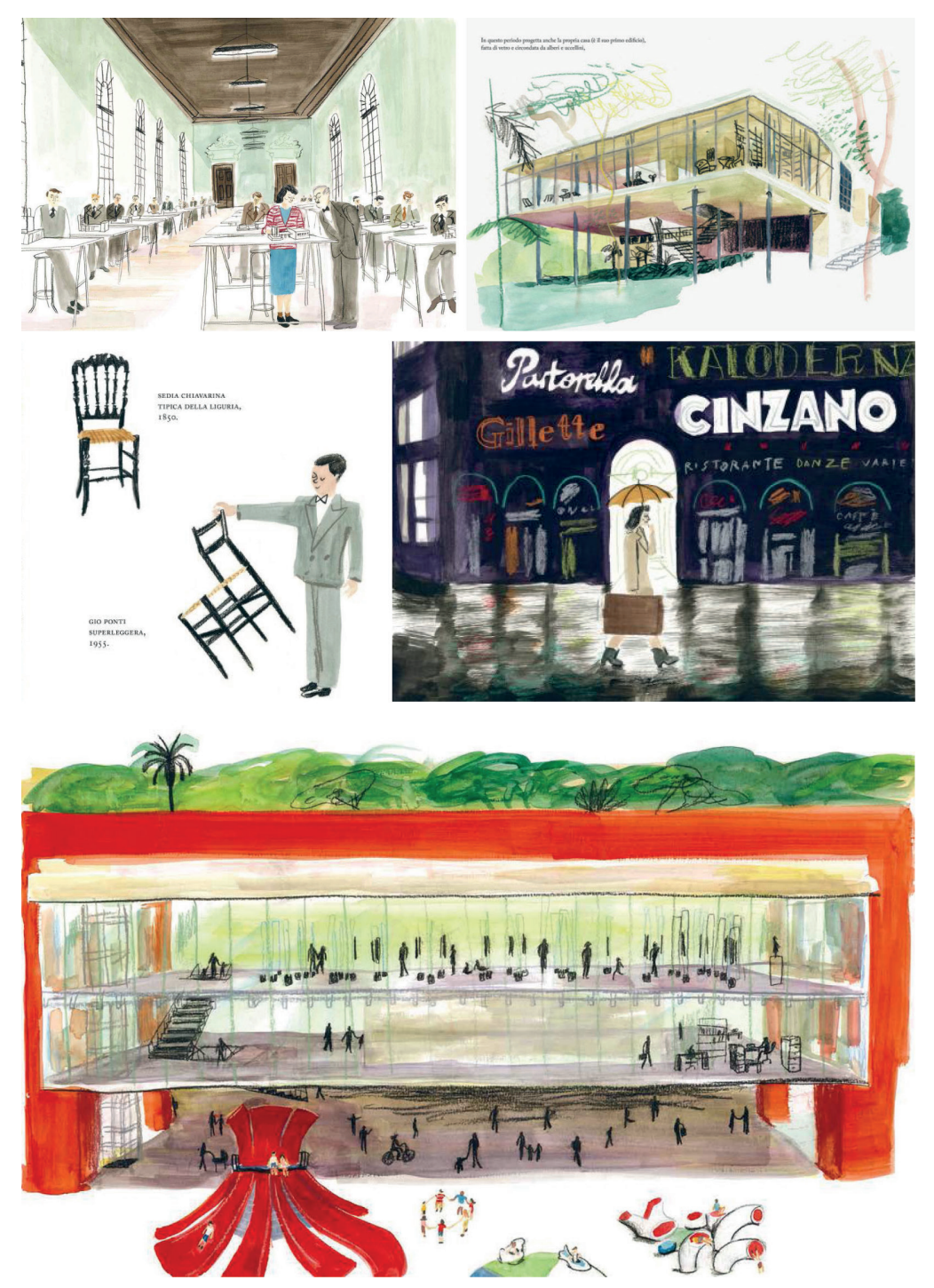
from her time in Japan. The layout of the drawings is quite traditional and follows a rigid compositional grid. The chromatic choices, the use of the graphic sign and the mixture of the techniques of representation are instead peculiar. A large part of the story is characterized by vignettes with a cream background, where the black stroke recalls the Japanese shodo, the art of traditional calligraphic writing. The whole work's style explicitly recalls oriental culture, thus becoming a symbol of the protagonist's influences and stylistic research. During her journey, various aspects of the traditional culture and craftsmanship of Japan were assimilated by Perriand, who internalized them and took inspiration for her own projects. This research is underlined by the author inserting checkered pages, like those of a travel notebook. These are sometimes in the foreground and other ones used as background for the conversations between Charlotte and a raven with glasses, an omnipresent symbolic figure of the master of the modern movement. Realism is not searched from the chromatic point of view. The color, influenced by the Japanese sumi-e ink technique, is emotional or symbolic. The dominant chroma is the blue, that is used in many of protagonist's reflective moments, in the nocturnal scenes or as an accent color for details, memories or important passages, such as the abandonment of the agency in order to be able to sign her own works or the study of traditional Japanese building techniques. Yellow and ochre are added in some landscape views, while red is introduced predominantly only to depict the attack on Pearl Harbor and the change in the political situation at the end of 194I. The second part of the
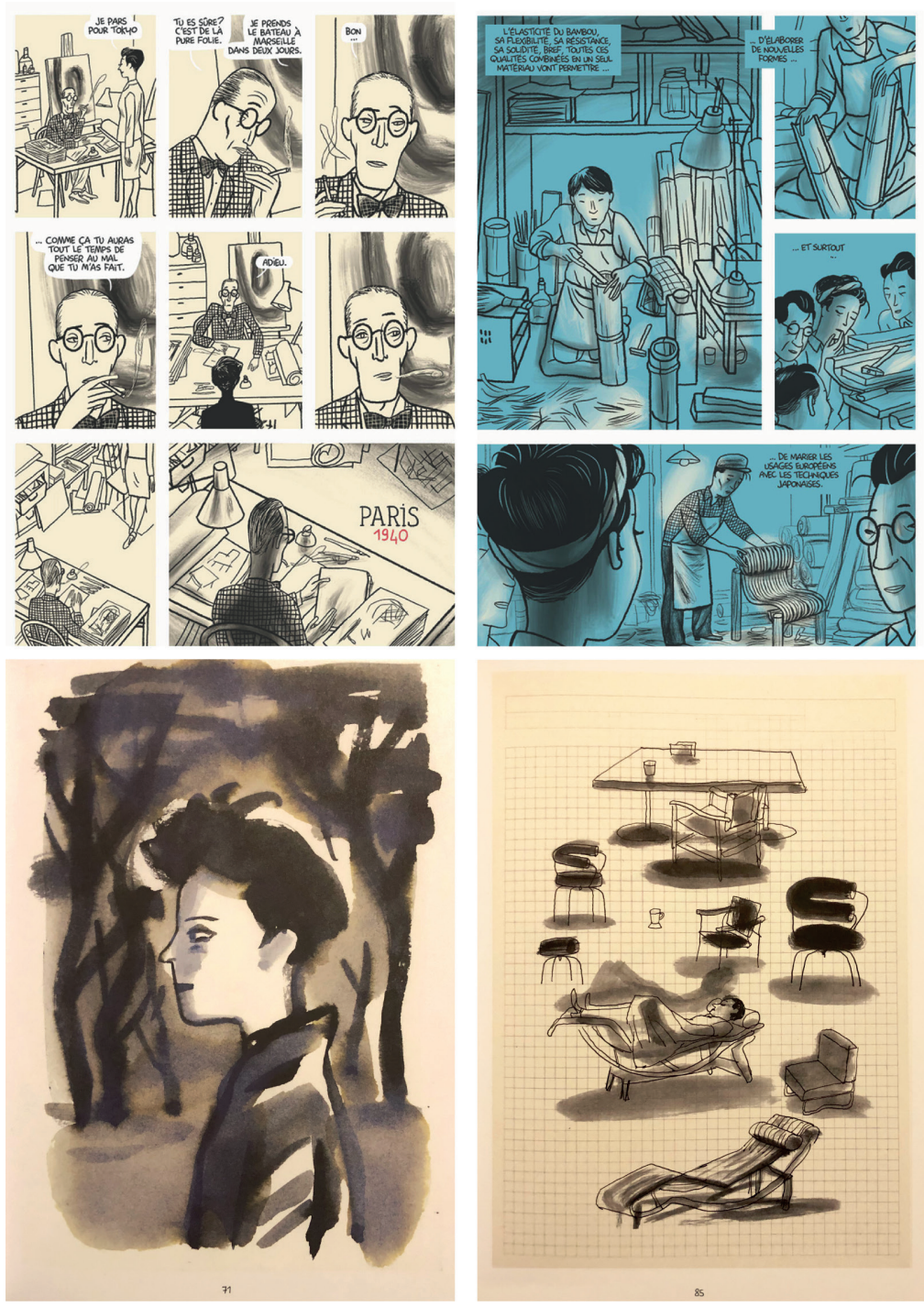
volume contains design sketches, often highlighting a background checkerboard, reintepreted into the style proposed by Berberian in the first part of the comic. These pages also focus on Japanese period details, showing typical traditional costumes, interiors, and people Charlotte Perriand relates to (fig. 6). A concise biography of the architect closes the work.

\title{
Conclusions
}

Architecture, instead of being a simple construction of places and spaces, is first of all the the designer's mind idea material projection, the vision materialization and the creation of an atmosphere. When comics narrative makes designers and architecture the protagonists of its stories, it focuses precisely on the narrative dimension. Indeed drawing, used both in comics and architecture, has the unique ability to show the concepts of time, space and movement in an effective and immediate way. The drawing is for comics and architecture a shared representation tool and as Will Eisner points out, in relation to the former, "it must be kept in mind that this medium is visual, and that the reader absorbs the 'tone' of the story and other abstract concepts through drawings" [Eisner 20I0, p. 33।].

The comics stories are a way to know the world as well as the architectural practice and they allow to catch aspects that often go unnoticed. For this reason, biographies of architects and designers in comics are referring to the indissoluble bond between the two practices and they represent an effective and convincing choice for the communication of immaterial contents that go beyond the project and beyond the designer. They also lend themselves to the expression of stylistic choices, which are communicated through drawing in a simple and intuitive way even to non-specialists.

\section{Notes}

[I] Although the paper was conceived jointly, Sara Conte is the author of the paragraphs Introduction and Interweaving between architecture and comics and the related images, Valentina Marchetti is the author of the paragraph Female comic book biographies and Conclusions and the related images.

\section{References}

Berberian C. (2019). Charlotte Perriand. Une architecte française au Japon (1940-1942). Paris: Editions du Chêne.

Berndt J. (1900). Manga and Manga: Contemporary Japanese Comics and their Dis/similarities with Hokusai Manga. In Civilisation of Evolution, Civilisation of Revolution, Metamorphoses in Japan 1900-2000, pp. 21 0-222.

Cassarà L., D'Urso S. (20 I3). Goodbye Topolinia.Catania: Malcor D'.

Eco U. (20।0). Apocalittici e integrati. Comunicazioni di massa e teorie della cultura di massa. Milano: Bompiani.

Eisner W. (20 I0). Fumetto e arte sequenziale. In W. Eisner. L'arte del fumetto. Milano: Bur Rizzoli.

Kinko I. (2008). Manga in Japanese History. In M. MacWilliams (Ed.). Japanese Visual Culture: Explorations in the World of Manga and Anime. Armonk, N.Y.: Sharpe, pp. 26-48.

Leon A. (2019). Lina. Avventure di un'architetta. Milano:Topipittori.

Malterre Barthes C., Dzierzawska Z. (2019). Eileen Gray: A House Under the Sun. London: Nobrow Press.

McCloud S. (1999). Capire il fumetto. L'arte invisibile. Torino:Vittorio Pavesio Editore.

\author{
Authors \\ Sara Conte, Politecnico di Milano, sara.conte@polimi.it \\ Valentina Marchetti, Politecnico di Milano, valentina.marchetti@polimi.it
}

To cite this chapter. Conte Sara, MarchettiValentina (2021). Progettisti a fumetti: quando la nona arte parla di progetto/Designers in comics: when the ninth art talks about design. In Arena A., Arena M., Mediati D., Raffa P. (a cura di). Connettere. Un disegno per annodare e tessere. Linguagg Distanze Tecnologie. Atti del $42^{\circ}$ Convegno Internazionale dei Docenti delle Discipline della Rappresentazione/Connecting. Drawing for weaving relationship. Languages Distances Technologies. Proceedings of the $42^{\text {th }}$ International Conference of Representation Disciplines Teachers. Milano: FrancoAngeli, pp. $548-565$. 